\title{
The Law Strength Of Under Hand Deed That Has Passed By Notary as an Authentic Deed in the Proof of Civil Case in District Court of Cirebon
}

\begin{abstract}
Yensih $^{1}$, Sukarmi ${ }^{2}$ and Lathifah Hanim ${ }^{3}$
Abstract. The purpose of this study was to determine: 1) The legal force under hand deed that has been approved by Notary as proof of the authentic deed in civil cases in District Court of Cirebon 2) The weakness of the legal strength under hand deed that has been approved by Notary as proof of the authentic deed in civil cases in District Court of Cirebon

The approach used in this paper is empirical juridical with the help of primary data or empirical data as the main data. Sources of primary data obtained through interviews, while secondary data obtained rehabilitated and reconstructed by literature. Data analysis techniques with descriptive analysis.

The final conclusion is:1.) The legal force under hand deed that has been approved by Notary as proof of the authentic deed in a civil case in court is not the same strength as the authentic deed, but the under hand deed could be evidence in a civil case in court, and the strength of the deed under hand legalized (legalization) Notary Having strength in numbers, the date, and the certainty of the signature of the parties. Under hand deed strength will be strong ruling legalizing if a Notary was brought to trial a witness to the truth of the deed under his hand legalized. 2) The weakness of the under hand deed, and that, if someone in the under hand deed does not admit the truth of the under hand deed strength is lost, but with the legalization of under hand deed can have the strength law even not same as authentic deed which has the perfect law strength.
\end{abstract}

Keywords : Deed under hand; Legalization; and Strength of evidence.

\section{Introduction}

In Article 1 of Act No. 2 of 2014 concerning amendments to the Act No. 30 of 2004 concerning Notary. Notary is an official with the State / public official authorized to make an authentic deed and other authorities referred to this legislation. It shall be divided into two types, namely the authentic deed and deed under hand. Under hand deed can be made in such a way on the basis of agreement between the parties and that important date can be made at any time. While the authentic deed is a deed (made) in the form prescribed by law, made by or in the presence of employees 2 general power to it, in a place where the deed made."4

The agreement also called approval or Overeenkomsten is "an agreement between two or more parties concerning the property of their wealth, which aims to bind both

\footnotetext{
${ }^{1}$ Student of Master of Notary Law, Faculty of Law, Sultan Agung Islamic University, Unissula, Semarang, email: yensihcrb@gmail.com

${ }^{2}$ Faculty of Law, Sultan Agung Islamic University, Unissula, Semarang

${ }^{3}$ Faculty of Law, Sultan Agung Islamic University, Unissula, Semarang

${ }^{4}$ https://acedadotco.wordpress.com/asal-usul-perjanjian-lama/ accessed October 22, 2019, at 19:00 pm.
} 
parties' agreement or contract is an event in which one person or one party promises to one or the other party or where two people or two parties mutually pledged to carry out a thing. ${ }^{5}$

As for in Article 1320 Book of Civil Law states that the terms validity of the agreement are: ${ }^{6}$

- The agreement of both parties. The purpose of the agreement is, both sides made an agreement to agree on matters central to the contract.

- Ability to conduct legal action. The principle of legal capacity, is any person who is already mature and healthy mind. Conditions have grown up, there are some opinions, according to the Civil Code, an adult is 21 years for men and 19 years for women.

- Their object / thing Certain Something agreed in an agreement to be a matter or thing is quite clear.

- Their lawful clauses.

The tool of evidence is one of the most important elements in proving civil case. The existence of evidence in the proof is very important because with evidence that the facts presented by party later on when it will be tested, clarified, and in correspondence with each other. Proving legal system in Indonesia basically adhere to closed and restricted evidentiary system. The verification system is based on the settings in Article 164 HIR / 284 R.BG and Article 1866 of the Civil Code which limit the evidence that is tool written evidence, witness evidence, conjecture, recognition and oath.

In the above description is based on Article 164 HIR / R.BG and Article 1866 of the Civil Code written evidence is the evidence first, main and highest in authentication system, among other evidence. ${ }^{7}$ Deed or deed abbreviated writing is writing that is signed and prepared/made for use as evidence in the interest of people for whom the certificate was made. ${ }^{8}$

There are two elements that must be fulfilled in order for a paper gain a qualification as a deed, namely: writing it must be signed and writing was made with the purpose to be used into evidence. But the under hand deed that has obtained the legalization give assurance to the judge about the date and the identity of the parties to the agreement and signature as required under the letter was no longer able to say that the parties or one party does not know what the contents of the letter it, because its contents have been read and explained before the party requiring his signature before the notary. Deed under hand will be referred to legally as evidence when the existing Regulation of Notaries and when the deed is a under hand deed, it must be in Waarmeking that only both sides would assume that knowing what's in the agreement, or in the legalization that all the contents of the agreement and the date of the agreement in known by Notary.

As an example the case of a civil case No. 42 / Pdt.G / 2010.PN.PDG Between PT. Suriatama Lestari (Plaintiff) against PT. Bakso Plaza (Defendant). Which at the time of the defendant to present evidence proving T.4 (Copy of Lease Agreement No. 067 / BMP / SP / PDG / II / 00 Date February 18, 2013, which is legalized by Notary and

\footnotetext{
5 The draft Civil Code Section 1313.

${ }^{6}$ Salim HS 2003, Perkembangan Hukum Kontrak Innominaat di Indonesia, Sinar Grafika, Jakarta, p. 10-11. ${ }^{7}$ M Natsir Aswani, 2013, Hukum Pembuktian Perkara Perdata di Indonesia, Yogyakarta, p. 34

${ }^{8}$ Arini Arini Sita, "Kedudukan Akta Di Bawah Tangan Yang Telah Dilegalisasi Notaris Dalam Pembuktian Di Pengadilan", February 2017 p. 79
} 
Volume 6 Issue 4, December 2019

Nationally Accredited Journal,

Decree No. B/4130/E5/E5.2.1/2019

PPAT BUDI ARIFIN SH, M.Kn., in the District of Cirebon. The background based on the description above, in this study the authors are interested in researching about the "Power of Hands Under the Deed Law That Has Passed Notary As proof of the authentic In Civil Cases in District Court of Cirebon".

This study sought to answer the problem of legal deed under hand which has passed the Notary as proof of the authentic deed in civil cases in the District Court of California, and the weakness of the legal strength under hand deed that has been approved by Notary as proof of the authentic deed in civil cases in District Court of Cirebon.

The purpose of this study was to determine: 1) The legal force under hand deed that has been approved by Notary as proof of the authentic deed in civil cases in District Court of Cirebon 2) The weakness of the legal strength under hand deed that has been approved by Notary as proof of the authentic deed in civil cases in District Court of Cirebon

\section{Research methods}

The approach used in this paper is empirical juridical with the help of primary data or empirical data as the main data. This research is a descriptive analysis, which is based on existing conditions according to the data obtained in the study, linked and compared with existing theories that fit the theme of the thesis. Sources of primary data obtained through interviews, while secondary data obtained rehabilitated and reconstructed by literature. Data were analyzed using descriptive analysis.

\section{Results and Discussion}

\subsection{Legally enforceable under hand deed that has passed the Notary as proof of the authentic deed in civil cases in the District Court of Cirebon}

Based on the shape, notarial deed is divided into two kinds of authentic deed and the under hand deed, which is described as follows:

- Authentic Deed which in English is called authentic deed, whereas in the Dutch language called the certificate authentieke van, ${ }^{9}$ which in Indonesia is regulated in Article 1868 of the Civil Code states authentic deed sense is "an act that is in the form prescribed by the law by or before the competent public authority for the place of the deed was made". Whereas in Article 1 point 7 UUJN mention also sense an authentic certificate, namely: "hereinafter referred to as the notarial deed is a authentic deed made by or before a notary in the form and manner set forth in this law".

- Under the deed in hand, under Article 1874 of the Civil Code states that: "which is regarded as the text below is a deed signed by hand under hand, letters, lists, letters household affairs and other writings made without the mediation of a public official".

\footnotetext{
9Salim HS.,2015, Teknik Pembuatan Akta Satu "Konsep Teoritis, Kewenangan Notaris Bentuk dan Minuta Akta", Ed-1, PT. Raja Grafindo Persada, Mataram, p. 17.
} 
In Cirebon court on civil case No. 42 / Pdt.G / 2010.PN.PDG Between PT. Suriatama Lestari (Plaintiff) against PT. Bakso Plaza (Defendant), there is one piece of evidence that copy of Lease Agreement legalized by Notary and PPAT BUDI ARIFIN SH, M.Kn., in Cirebon. The evidence is the under hand deed that was authorized by the Notary, raising the question of how the strength of that evidence.

Article 1874 of the Civil Code states that: "The treated as writing under the hand is a deed signed under hand, letters, lists, letters household affairs and other writings made without the mediation a public official ".

Article 1902 of the Civil Code raised about the conditions when there is written evidence, namely:

- There must be a deed.

- It shall be made by the person against whom made demands or of the person represents.

Under hand deed has the characteristics and its own peculiarities, such as:

- The form is free

- The act not necessarily in the presence of officials general

- Still have the strength of evidence for not denied by the manufacturer, meaning that the contents of the deed does not need to be proven again unless anyone can prove otherwise (Deny it).

In case must be proved, then the proof shall be equipped also with witnesses and other evidence. Therefore, usually in under hand deed should be included 2 people adult witnesses to strengthen as a result of law.

Notary of the tasks and work is not limited to making authentic deed but also assigned the registration and attestation letters below the usual hand-in legalization and waarmerking, and make a copy of the letter under the hand and approved similarity of photocopy with the original letter.

- Legalization is under the Deed of hands has not been signed and submitted to the Notary and at that moment the Notary read and explain the contents of the under hand deed to the parties, and subsequently signed by the parties. The parties know the contents of the deed.

- Waarmerker ie underhand deed signed by the parties and then submitted to the Notary to register the date of the under hand deed, only guarantee the date and time of registration only. There is no assurance of a signature and date of the deed under hand.

In Article 15 paragraph (2) letter a Notary Law, the Notary, in his post, authorities certify the signatures and set a firm date in the letter under the hand, by enrolling in a special book. Legalization provisions of the under hand deed, which are made by individuals, or by the parties, on paper that is stamped, with the registration in a special book, which is provided by a Notary. Legalization is, the parties make the letter, brought to the Notary and signed before Notary, then recorded in the Book of legalization. Date upon signing the Notary, as the date of the legal act, which create the rights and obligations between the parties.

Legalization of signatures and the establishment of certainty the date, recorded in a special book, which is the book Legalization. Notaries who witness and certify signatures, set a firm date, as an officer authorized by law to explain / justify / make sure that the correct on the date written in the Book Legalization, the parties make an 
Volume 6 Issue 4, December 2019

Nationally Accredited Journal,

Decree No. B/4130/E5/E5.2.1/2019

agreement under the hands and face him to sign the letter. Editorial written on the legalization sheet, to the extent that liability Notary.

Regarding the procedure of legalization qualified by the sound of a Civil Code Article 1874:

- Signer certificates (the parties) in the know or be introduced to the Notary.

- Before the deed was signed by the client, a notary must first be read out its contents.

- Then the client deed is signed before a Notary.

Deed under new hands have formal proof strength, if the signatures under the deed was recognized / not indisputably correct. With the recognition of the authenticity of the signature on the under hand deed, then the power of formal proof of the under hand deed together with the power of formal proof of an authentic deed. A certificate under the hand that is recognized by the person against whom the deed was to be used, or by way of statutory considered as recognized, give it to the people who have the right than they were, the evidence is perfect as an authentic deed. ${ }^{10}$

In ambtelijke akten, officials maker that deed explains what constantium by officials and write it in deed, and therefore what is described by the NII officials had been certain for anyone, as long as the date of creation, place a deed and content / information in the deed. In Partij akten as authentic deeds, for whoever has certainty that the parties and officials concerned expressed as what is written on their signature. Under hand deed contains also a record of a legal act, but the difference between an authentic deed, that the under hand deed is not made before a public servant, but by the parties themselves. The strength of evidence is generally owned by an authentic deed, does not exist in the under hand deed. Under hand deed only has the power of formal proof, that is when the signature on the certificate is recognized (and this is already an admission of evidence) which means that the statement contained in the certificate is recognized and justified. Under these conditions, the contents of the deed recognized, is earnest statement the parties concerned, what is undeniable is that the statement was made on the date indicated in the deed, because the date is not including the contents of the statement the parties concerned.

Under these conditions, the strength of the under hand deed as evidence against third parties regarding the content of his statements quite different than that on the date the deed. Under hand deed that is recognized is a proof against anyone, for the correctness of the statement anyone else, for the correctness of the statement of the parties made in the deed of it in the form that can be touched and can be seen, however, that the statement was made On the written in the deed, only a certainty for the parties who signed the deed and the heirs of the parties as well as those who receive their rights. ${ }^{11}$

In the case concerned want, can also be in the letters under the hands given the information which was dated by a notary public or other personnel designated by law that states that the person who signed the letter were unknown to him or introduced to him, that the contents of the deed is explained clearly to the man and that after the deed was signed before the employee's letters under the hand that is recognized by

\footnotetext{
${ }^{10}$ Article 1875 of the Civil Code

${ }^{11}$ Interview with Sri Anah (Notary / PPAT), Cirebon, On Date October 20, 2019.
} 
the people to whom the letter was the exercise or deemed recognized by legitimate means should be proof enough as an authentic deed of the signatory and their heirs and who get their rights. Thus the judge must consider the true contents of the deed along can not be proved by the opponent to lack truth.

Strength under hand deed that has been legalized by a notary has the same power as the authentic deed if both parties recognize the truth of the under hand deed, but the strength of the under hand deed can not be accepted by the judge, despite being notarized, because the force of law under hand deed unlike authentic deed of the obvious certainty of legal force. But the under hand deed can also be received if a notary who made the legalization brought to the court, then the strength of the under hand deed that has been legalized is perfectly legal effect as a authentic deed.

Under these conditions, the under hand deed that has obtained the legalization of notary assist judges in terms of proof as to the recognition of the signature then the contents of the deed was regarded as an agreement between the parties for the under hand deed of the truth lies in the signatures of the parties, with the recognition of signatures, certificates the evidence is perfect.

\subsection{Weakness from enforceable under hand deed that has passed the Notary as proof of the authentic deed in civil cases in the District Court of Cirebon}

In running position, subject to the Notary Act No. 30 of 2004 concerning Notary, as amended by Act No. 2 2014. In Article 15 paragraph 2 letter a Notary Law, in his authorized notary certify the signatures and set a firm date in the letter under the hand, by enrolling in a special book, which is provided by a notary. This provision, the legalization of the under hand deed, that is made by an individual, or by the parties, on paper that is stamped, with the registration in a special book, which is provided by a notary. Besides the notary is also responsible to explain, justify, and to make sure that the correct on the date written in the book of legalization. ${ }^{12}$ Notary Deed specifically regulated in Article 1 paragraph 7 UUJN, while setting an authentic deed in article 1868 of the Civil Code, this article has been a source of authenticity of a notarial deed which also is the basic legality of the existence of a notarial deed which has requirements that:

- Deed must be made before a public official.

- Deed must be made in the form prescribed by law.

- Deed made by or before the competent public authority for it and where the deed was made. ${ }^{13}$

Sri Anah, SH., M.Kn said that a under hand deed can not be used as an authentic deed for her in the authentic deed contains legislation that has been set by the government, but its strength is stronger authentic deed and nobody can sue. ${ }^{14}$

Authentic deed of a criminal offense is perfect but the deed under hand there are weaknesses law, if someone in the under hand deed does not admit the truth of the

\footnotetext{
${ }^{12 L}$. Gerungan, Jurnal Hukum Vol. XX No. 1, January-March 2012, p. 10.

${ }^{13}$ Mas Mas Maya Ramantini, Tanggungjawab Notaris Dalam Pembuatan Minuta Akta Yang Dibuat Berdasarkan Keterangan Palsu Oleh Para Pihak, (Thesis, Faculty of Law Udayana University, Denpasar, 2014) p. 56.

${ }^{14}$ Interview with Sri Anah (Notary / PPAT), Cirebon, On Date October 20, 2019.
} 
Volume 6 Issue 4, December 2019

Nationally Accredited Journal,

Decree No. B/4130/E5/E5.2.1/2019

under hand deed then his strength will be lost, but with the legalization of the under hand deed can be legally enforceable however unlike the authentic deed is perfect legal force.

So the under hand deed is not a legal effect the perfect proof of being located at the signatures of all parties in the agreement. A certificate under the hand merely give legal effect to the perfect proof for the benefit of parties to whom signed about to give evidence, while the legal consequences for third parties of proof is free. This is different Unlike the authentic deed that has the strength of evidence was perfect, then to the under hand deed strength of the proof is in the hands of judges to consider it (Article 1881 (2) Civil Code).

\section{Closing}

\subsection{Conclusions}

Based on the description set forth above, it can be summed up as follows:

- Legally enforceable under hand deed that has been approved by Notary as the authentic deed in proving the civil case in court that the practice of legalization by notary that legalization is a recognition of the date of the agreement, so the under hand deed that has obtained the legalization give assurance to the judge about the date, identity, as well as the signatures of the parties. In this case the parties can no longer say that the parties do not know what the contents of the letter, because the contents of the under hand deed has been read by the Notary before added the autographs before the public official concerned and in front of witnesses. However enforceable under hand deed strength is not the same as an authentic deed, but the under hand deed could be evidence in a civil case in court, and the strength of the under hand deed that has been approved (Legalization) Notary Having strength in numbers, the date, and the certainty of the signature of the parties. Under hand deed strength will be strong ruling legalizing if a Notary was brought to trial a witness to the truth of the deed under his hand legalized.

- The weakness of the under hand deed, and that, if someone in the under hand deed does not admit the truth of the under hand deed then the strength is lost, but with the legalization of the under hand deed could have the force of law but not as authentic deeds are legal force is perfect.

\subsection{Suggestion}

Based on the above conclusions, the authors can provide suggestions as follows:

- Each will perform a contract or agreement concerning the parties, should be created with the Notary deed, so that the legal effect of proof if an when required to have strength and strong clear evidence or its legal consequences has perfect proof.

- With the authentic deed is very helpful judges to consider in making a decision because of a notarial deed, it is already in the know of all parties concerned and are made in the presence of a Notary by witnesses Notary know as well as notary can be a witness if necessary.

\section{References}


[1] Ali Ahmad, SH., MH, 2012, Asas-Asas Hukum Pembuktian Perdata, Kharisma Putra Utama, Jakarta.

[2] Emzir, 2012, Metodologi Penelitian Kualitatif Analisis Data, Raja Grafindo Persada, Jakarta.

[3] Civil Laws Code

[4] Komar Andasasmita, Akta II Notaris dan Contoh-contoh Akta, Ikatan Notaris Indonesia, 2007

[5] L. Gerungan, Jurnal Hukum Vol. XX No. 1, January-March 2012

[6] M Natsir Aswani, 2013, Hukum Pembuktian Perkara Perdata di Indonesia, Yogyakarta

[7] Putu Mas Maya Ramantini, Tanggungjawab Notaris Dalam Pembuatan Minuta Akta Yang Dibuat Berdasarkan Keterangan Palsu Oleh Para Pihak, (Tesis, Faculty of Law of Udayana University, Denpasar, 2014)

[8] R. Subekti, 2001, Pokok-Pokok Hukum Perdata, Intermasa, Jakarta.

[9] Salim H.S, 2003, Perkembangan Hukum Kontrak Innominaat di Indonesia, Sinar Grafika, Jakarta.

[10] Salim HS.,2015, Teknik Pembuatan Akta Satu "Konsep Teoritis, Kewenangan Notaris Bentuk dan Minuta Akta", Ed-1, PT. Raja Grafindo Persada, Mataram.

[11] Soerjono Soekanto, 1986, Pengantar Penelitian Hukum, Ed. 3, UI-Press, Jakarta.

[12] Umbas Arini Sita, "Kedudukan Akta Di Bawah Tangan Yang Telah Dilegalisasi Notaris Dalam Pembuktian Di Pengadilan", February 2017 